\title{
IMMUNOPHENOTYPIC AND GENOTYPIC CHARACTERIZATION OF NASAL LYMPHOMA WITH POLYMORPHIC RETICULOSIS MORPHOLOGY
}

\author{
Masahiko Ohsawa ${ }^{1}$, Shin-ichi NaKatsuKa ${ }^{1}$, Hiroyuki Kanno ${ }^{1}$, Hideaki Miwa ${ }^{1}$, Shizuo KoJYA ${ }^{2}$, Yasuaki Harabuchi ${ }^{3}$, \\ Woo-Ick YANG ${ }^{4}$ and Katsuyuki AOZASA ${ }^{1 *}$ \\ ${ }^{1}$ Department of Pathology, Osaka University Medical School, Osaka, Japan \\ ${ }^{2}$ Department of Otorhinolaryngology, University of Ryukyus, Faculty of Medicine, Okinawa, Japan \\ ${ }^{3}$ Department of Otorhinolaryngology, Sapporo Medical University, Sapporo, Japan \\ ${ }^{4}$ Department of Pathology, Yonsei University College of Medicine, Seoul, Republic of Korea
}

Nasal lymphoma with polymorphic reticulosis (PR) morphology is now categorized as T/natural killer (T/NK) cell lymphoma. In this study, immunophenotypes and genotypes of proliferating cells in $\mathbf{2 1}$ cases with PR were examined. The patients included 13 men and 8 women ranging in age from 20 to 74 (median 37) years. All patients presented with lesions in the upper respiratory tract, mostly in the nasal cavity. Histological specimens obtained from the primary lesions (19 cases) and metastatic cervical lymph nodes (2 cases) were used for analyses. Histologically, polymorphous proliferation was found in 20 cases, and these were thus diagnosed as PR. A monomorphous pattern was found in the remaining last case. Immunohistochemical analysis revealed that the proliferating cells were CD56 $(123 \mathrm{C} 3)^{+}$and/or CD16 $(2 \mathrm{H7})^{+}$, TIA-1 ${ }^{+}$ and frequently stained $\operatorname{CD} 3 \epsilon^{+}$. Tumor cells were frequently stained positively with monoclonal antibodies (mAbs) for $T$ lymphocytes, but were negative for T-cell receptor (TCR) $\beta$ and $\delta$ chain expression. In situ hybridization analysis using an Epstein-Barr virus-encoded early RNA 1 (EBER-1) probe revealed positive signals in $\mathbf{1 3}$ of the 15 cases examined. Southern blotting analysis for clonality of the Epstein-Barr virus (EBV) genome in 12 positive cases confirmed the presence of monoclonal proliferation in 7 cases. The pattern of TCR $\gamma$ chain gene rearrangement was examined by PCR analysis of DNA from tumor tissues by the denaturing gradient gel electrophoresis method. The results demonstrated no clonal rearrangement in any of the 21 cases examined, including 7 cases with proven clonal proliferation of EBV-infected cells, indicating the absence of T-cell clones. Our findings strongly suggested that nasal T-cell lymphoma is in fact a NK cell lymphoma. Int. J. C ancer 81:865-870, 1999.

(c) 1999 Wiley-Liss, Inc.

Nasal lymphoma frequently exhibits a polymorphous pattern of proliferation consisting of large atypical cells with mono- or multinucleus, small lymphocytes, plasma cells, benign-appearing macrophages, neutrophils and much less frequently eosinophils. For this, the term polymorphic reticulosis (PR) was proposed (Kassel et al., 1969). PR constitutes a clinical condition of lethal midline granuloma (LMG) which is characterized by necrotic and granulomatous lesions affecting the upper respiratory tract, especially the nasal cavity. Malignant lymphoma with monomorphous proliferation and Wegener's granulomatosis also show a condition similar to LMG.

Ishii et al. (1982) demonstrated that the proliferating cells in PR exhibit the T-cell immunophenotype by immunohistochemical analysis using polyclonal anti-T-cell antibody. Therefore, they proposed the term nasal T-cell lymphoma (NTL). However, monoclonal rearrangement of the T-cell receptor (TCR) genes has seldom been found in cases with NTL. Later, $\mathrm{Ng}$ et al. (1987) reported that tumor cells in this type of lymphoma showed positive immunoreactivity for the natural killer (NK) cell marker CD56. Immunophenotypic and genotypic studies of NTL have yielded contradictory results regarding the nature of tumor cells, i.e., NK cells $\left(\mathrm{CD}^{+} 6^{+}\right.$and germline TCR $\beta, \gamma, \delta$ genes) (Emile et al., 1996; Petrella et al., 1996), NK-like T cells $\left(\mathrm{CD}^{2} 6^{+}\right.$and rearrangement of TCR genes) (Chiang et al., 1996) or T cells (CD56- and rearrangement of TCR) (Harabuchi et al., 1996). These discrepancies may have been due to the small number of cases examined, limitations of the methods used or the diseases themselves being heterogeneous. A workshop on the nasal and related extranodal T/NK cell lymphomas recommended the provisional terminology "nasal and nasal-type T/NK cell lymphoma" since the precise lineage of the neoplastic cells has not been demonstrated (Jaffe, 1996).

PCR-based strategies for analysis of gene rearrangement have become widespread (Hodges et al., 1994). Denaturing gradient gel electrophoresis (DGGE), originally developed to detect point mutations, can separate PCR products according to their unique DNA sequences and not their length (Bourgium et al., 1990; Theodorou et al., 1996). Therefore, this method has a greater degree of specificity and 5- to 10-fold higher sensitivity than Southern blotting analysis (Bourgium et al., 1990). In our study, the DGGE method was employed to examine the rearrangement of TCR $\gamma$ chain genes in NTL. Rearrangement of TCR $\gamma$ and $\delta$ chain genes precedes that of the $\beta$ gene; thus, detection of rearrangement of the $\gamma$ chain gene is more sensitive than that of the $\beta$ chain (Theodorou et al., 1996).

We examined the immunophenotypes and genotypes of proliferating cells in 21 cases with NTL, one of the Epstein-Barr virus (EBV)-associated lymphomas (Harabuchi et al., 1990; Tomita et al., 1995). Circularization of the EBV genome produces EBV episomes that have variable numbers of terminal repeats (TR) that differ between individual clones, and the presence of a single predominant band containing TR represents the clonal cellular proliferation of EBV-infected cells (Raab-Traub et al., 1986). Thus, we examined the presence of clonal proliferation by determining patterns of fused TR of EBV.

\section{PATIENTS AND METHODS}

\section{Patients}

Review of our consultation files during the period from 1986 to 1997 revealed 17 cases (14 Japanese and 3 Chinese) of nasal lymphoproliferative diseases with histological features of PR and/or positive immunoreactivity of the proliferating cells for T-cell markers. Fresh frozen and paraffin-embedded specimens were available for 13 patients. Fresh frozen specimens and hematoxylin-eosin (H\&E)-stained sections were available for 1 Japanese and 3 Chinese patients. In addition, fresh frozen and paraffin-embedded specimens from 4 Korean patients with PR were available; these patients had been admitted to Yonsei University Hospital, Seoul, in 1997. All these patients had the clinical

Grant sponsor: Ministry of Education, Science and Culture, Japan; Grant numbers: 08457061; 08670202; 08770126; 09670184; 09770148; Grant sponsor: Vehicle Racing Commemorative Foundation.

*Correspondence to: Department of Pathology (C3), Osaka University Medical School, 2-2 Yamadaoka, Suita, Osaka 565-0871, Japan. Fax: (81) 6-879-3713. E-mail: aozasa@molpath.med.osaka-u.ac.jp

Received 10 October 1998; Revised 28 December 1998 
features of LMG, i.e., presence of necrotic granulomatous lesions in the upper respiratory tract. A total of 21 cases were included in our study: age at first admission ranged from 20 to 74 (median 37) years, and the subjects comprised 13 men and 8 women. The primary lesion was found in the nasal cavity in 18 patients, and in the epipharynx, nasopharynx and soft palate in 1 case each. Histological specimens, obtained from the primary lesions (19 cases) and metastatic cervical lymph nodes (2 cases), were fixed in $10 \%$ formalin and routinely processed for paraffin-embedding. Fresh specimens biopsied from the primary lesion were snap frozen in liquid nitrogen and stored at $-80^{\circ} \mathrm{C}$ until use. All histological specimens were reviewed by one of the authors (K.A.), and a diagnosis of PR was made in 20 cases and of diffuse mixed cell type non-Hodgkin's lymphoma (NHL) in 1 case.

\section{Immunohistochemistry}

Staining by the avidin-biotin-peroxidase complex method was carried out on paraffin-embedded specimens in 16 cases and on fresh frozen specimen in 2 cases (1 and 2). The monoclonal antibodies (mAbs) and polyclonal antisera used for staining paraffin sections, their reactivity and suppliers are listed in Table I. Sections were treated with $0.1 \%$ trypsin solution (Sigma, St. Louis, $\mathrm{MO})$ at $37^{\circ} \mathrm{C}$ for $30 \mathrm{~min}$ or $40 \mathrm{~min}$ before reaction with $\beta \mathrm{F} 1$ or anti-CD3, respectively. When 4C7, C8/144B, 2H7, 123C3, Leu7, CS1-4 and PE2 were used as primary antibody, sections were treated in a microwave oven for $15 \mathrm{~min}$ in $0.01 \%$ citrate buffer $(\mathrm{pH}$ 6) for antigen retrieval. Sections were microwaved for $15 \mathrm{~min}$ in 1 mM EDTA ( $\mathrm{pH}$ 8.0) before incubation with 1F6. Cryocut sections in cases 1 and 2 were stained with anti-CD2 and TCR $\delta$ antibodies together with the antibodies used on paraffin sections. Five cases of nodal lymphoma of proven B- and T-cell immunophenotypes were included as controls.

\section{In situ hybridization for $E B V$}

EBV RNA in situ hybridization was performed as previously described (Weiss et al., 1991) with some modifications. Briefly, 30-base sense and antisense oligonucleotide probes corresponding to a portion of the EBV-encoded early RNA 1 (EBER-1) gene, a region of the EBV genome that is actively transcribed in latently infected cells, were synthesized using a DNA synthesizer. As a positive control, the Raji cell line was used. As negative controls, hybridization was performed with a sense probe (a) and an antisense probe (b) after RNAse treatment. All controls for each case were run in parallel in each experiment.

\section{DGGE method}

Fresh frozen specimens obtained from 21 patients were available for DGGE analysis. To analyze the TCR $\gamma$ gene configuration, we used a modification of the method of Theodorou et al. (1996). Briefly, we used 4 sets of $5^{\prime}$ primers designed for the $\mathrm{V}_{\gamma}$ families and 4 sets of $3^{\prime}$ primers designed for the different $\mathrm{J}$ genes; the sequences of these primers were described previously (Theodorou et al., 1996). A 40-nucleotide GC clamp was attached at the $5^{\prime}$ end of each $\mathrm{V}_{\gamma}$ primer. All primers were purified by high performance liquid chromatography. For assessment of clonality, 1 of $4 \mathrm{~V}_{\gamma}$ primers and a mixture of $4 \mathrm{~J}$ primers were used in a single reaction (hemimultiplex PCR). When a rearranged band was found in hemimultiplex PCR, pairwise analysis (monoplex PCR) was performed with all VJ primer combinations to identify the $\mathrm{V}$ and $\mathrm{J}$ genes involved in rearranged alleles. DNA was prepared by proteinase $\mathrm{K}$ digestion, followed by phenol/chloroform extraction. The reaction mixture containing $250 \mathrm{ng}$ of genomic DNA, $5 \mu \mathrm{l}$ of $10 \times$ reaction buffer, $200 \mu \mathrm{M}$ dNTPs, 0.8 or $1.2 \mu \mathrm{M}$ of the selected $\mathrm{V}_{\gamma}$ primer and $0.8 \mu \mathrm{M}$ of the $4 \mathrm{~J}_{\gamma}$ primers was dissolved in a final volume of $50 \mu \mathrm{l}$ and overlaid with 1 drop of mineral oil. After initial denaturation at $94^{\circ} \mathrm{C}$ for $5 \mathrm{~min}$, PCR was hot-started by adding 1.5 $\mathrm{U}$ of Taq polymerase (Wako, Osaka, Japan). PCR was performed with 40 cycles of denaturation at $94^{\circ} \mathrm{C}$ for $1 \mathrm{~min}$, annealing at $56^{\circ} \mathrm{C}$ for $1 \mathrm{~min}$ and extension at $72^{\circ} \mathrm{C}$ for $2 \mathrm{~min}$. A final extension at $72^{\circ} \mathrm{C}$ was performed for $6 \mathrm{~min}$. Before DGGE, aliquots of $10 \mu \mathrm{l}$ of PCR products were screened by agarose gel electrophoresis in $1.5 \%$ agarose gels with TBE buffer $(100 \mathrm{mM}$ Tris base, $90 \mathrm{mM}$ boric acid, $1 \mathrm{mM}$ EDTA, $\mathrm{pH}$ 8.3) to confirm desirable amplification of DNA fragments with the expected sizes. For DGGE analysis, aliquots of $40 \mu \mathrm{l}$ of PCR products were run on a $6.5 \%$ polyacrylamide gel containing a linear $10-60 \%$ denaturing gradient $(100 \%$

TABLE I - ANTIBODY PANEL

\begin{tabular}{|c|c|c|c|c|}
\hline Antibody & CD number & Reactivity & Dilution rate & Source \\
\hline \multicolumn{5}{|c|}{$\begin{array}{l}\text { Paraffin and cryostat } \\
\text { sections }\end{array}$} \\
\hline Mx-pan B & $\mathrm{CD} 20$ & Pan B cell & $1: 50$ & $\begin{array}{l}\text { Kyowa Medex (Tokyo, } \\
\text { Japan) }\end{array}$ \\
\hline MB-1 & - & Pan B cell & $1: 50$ & $\begin{array}{l}\text { Bioscience (Emmen- } \\
\text { brücke, Switzerland) }\end{array}$ \\
\hline MT-1 & CD43 & Pan T cell & $1: 50$ & Bioscience \\
\hline UCHL-1 & CD45RO & Pan T cell & $1: 100$ & $\begin{array}{l}\text { Dakopatts (Glostrup, } \\
\text { Denmark) }\end{array}$ \\
\hline Anti-CD3 $\epsilon$ & $\mathrm{CD} 3 \epsilon$ & Pan T cell & $1: 100$ & Dakopatts \\
\hline 1F6 & CD4 & Helper/inducer T cell & $1: 200$ & $\begin{array}{l}\text { Novocastra (Newcastle } \\
\text { Upon Tyne, UK) }\end{array}$ \\
\hline $4 \mathrm{C} 7$ & CD5 & $\mathrm{T}$ cell, mantle zone B cell & $1: 200$ & Novocastra \\
\hline C8/144B & CD8 & $\begin{array}{l}\text { Cytotoxic/suppressor T } \\
\text { cell }\end{array}$ & $1: 200$ & Dakopatts \\
\hline LeuM1 & CD15 & Granulocyte, macrophage & $1: 50$ & $\begin{array}{l}\text { Becton-Dickinson (San } \\
\text { Jose, CA) }\end{array}$ \\
\hline $2 \mathrm{H} 7$ & CD16 & Nk cell & $1: 200$ & Novocastra \\
\hline $123 \mathrm{C} 3$ & CD56 & NK cell & $1: 40$ & $\begin{array}{l}\text { Zymed (South San Fran- } \\
\text { cisco, CA) }\end{array}$ \\
\hline Leu7 & CD57 & NK cell & $1: 20$ & Becton-Dickinson \\
\hline$\beta$ F1 & - & TCR $\beta$ chain & $1: 50$ & $\begin{array}{l}\text { T Cell Diagnostics } \\
\text { (Woburn, MA) }\end{array}$ \\
\hline $\mathrm{CS} 1-4$ & - & Latent membrane protein ${ }^{-1}$ & $1: 20$ & Dakopatts \\
\hline PE2 & - & EBNA2 & $1: 20$ & Dakopatts \\
\hline TIA-1 & - & Cytotoxic granules & $1: 500$ & Coulter (Hialeah, FL) \\
\hline \multicolumn{5}{|c|}{ Cryostat sections } \\
\hline Leu 5b & $\mathrm{CD} 2$ & Pan T cell, NK cell & $1: 50$ & Becton-Dickinson \\
\hline TCR $\delta 1$ & - & TCR $\delta$ chain & $1: 50$ & T Cell Diagnostics \\
\hline
\end{tabular}

${ }^{1} \mathrm{CD}$ number, cluster of differentiation number; EBNA2, EBV nuclear antigen 2; NK cell, natural killer cell. 
denaturant $=7 \mathrm{M}$ urea and $40 \%$ volume of solute per volume of solution formamide) in TAE buffer (40 mM Tris base, $20 \mathrm{mM}$ sodium acetate, $1 \mathrm{mM}$ EDTA, $\mathrm{pH}$ 7.4). The dimensions of gels were $16 \mathrm{~cm} \times 16 \mathrm{~cm} \times 1 \mathrm{~mm}$. PCR products were precipitated in a solution containing $0.3 \mathrm{M}$ sodium acetate and $70 \%$ ethanol at $-20^{\circ} \mathrm{C}$, and resuspended in $20 \mu \mathrm{l}$ of loading buffer (20\% Ficoll/10 $\mathrm{mM}$ Tris, $\mathrm{pH}$ 7.8/1 mM EDTA/0.5\% bromphenol blue), incubated at $95^{\circ} \mathrm{C}$ for $5 \mathrm{~min}$, rapidly cooled and held at $60^{\circ} \mathrm{C}$ for $1 \mathrm{hr}$ prior to loading onto the gels. Gels were run at $150 \mathrm{~V}$ for $5 \mathrm{hr}$ in TAE buffer at $60^{\circ} \mathrm{C}$. After electrophoresis, gels were stained with ethidium bromide and photographed under UV illumination.

Clonal rearrangement of the TCR $\gamma$ gene results in 1 (monoallelic) or 2 (biallelic) bands on DGGE, whereas polyclonal rearrangement results in a smear. DNA extracted from 6 T-cell lines (Jurkat, Molt-4, Molt-14, HSB2, RPMI8402, Peer) with well-characterized TCR $\gamma$ gene configurations and from a lymph nodal lesion in 1 case of peripheral T-cell lymphoma were used to establish the efficacy of the primers in DGGE procedures. HSB2 and 3 T-cell lines including Molt-14, RPMI8402 and Peer were gifts from the Human Science Research Resource Bank, Hayashibara Biochemical Laboratories, Inc., and Fujisaki Cell Center. DNA extracted from lymphocytes in peripheral blood of normal individuals (4 cases) and reactive lymphadenitis (1 case) with no monoclonal TCR $\gamma$ gene rearrangement were used as negative controls. When DNA from a clonal T-cell line was serially diluted with DNA extracted from lymphocytes from a normal individual, the sensitivity of this system was estimated to be lower than $5 \%$ in all hemimultiplex primer combinations. Usage of monoplex PCR increases the sensitivity to $0.1 \%$. The experiment was repeated twice for each sample.

\section{Southern blotting analysis for EBV genome clonality}

Aliquots of 10 or $20 \mu \mathrm{g}$ of DNA were digested with Bam HI (GIBCO-BRL, Gaithersburg, MD), electrophoresed in $0.6 \%$ agarose gels and subjected to Southern blotting. The plasmid containing the joined termini of EBV genome, pCB 281, was kindly provided by Dr. E. Kieff (Boston, MA). The $1.9 \mathrm{~kb}$ Xho-I fragment adjacent to TR was used as a template and the probe was labeled with $\alpha-\left[{ }^{32} \mathrm{P}\right]-\mathrm{dCTP}$ by random priming.

Southern blotted filters were prehybridized for $4 \mathrm{hr}$ at $42^{\circ} \mathrm{C}$ in $6 \times \operatorname{SSPE}(0.9 \mathrm{M} \mathrm{NaCl}, 0.06 \mathrm{M}$ Na phosphate, $6 \mathrm{mM}$ EDTA), $5 \times$ Denhardt's solution, $0.1 \%$ SDS, $200 \mu \mathrm{g} / \mathrm{ml}$ denatured salmon testes DNA (Sigma) and 50\% formamide, and hybridized in a solution of the same composition containing the probe at $2 \times 10^{6} \mathrm{cpm} / \mathrm{ml}$. Filters were hybridized for $20 \mathrm{hr}$ at $42^{\circ} \mathrm{C}$, washed twice for $30 \mathrm{~min}$ at room temperature with $1 \times$ SSPE, $0.1 \%$ SDS, and twice for 20 min at $70^{\circ} \mathrm{C}$ with $0.1 \times \mathrm{SSPE}, 0.1 \%$ SDS, and exposed at $-80^{\circ} \mathrm{C}$.

\section{RESULTS}

\section{Histological findings}

The primary lesions showed varying degrees of necrosis. Diffuse proliferation of large atypical mono- or multinucleated cells intermingling with various numbers of small lymphocytes, plasma cells and macrophages was observed, giving a more or less polymorphous appearance in all but 1 case (Fig. 1). Angiodestructive pattern of proliferation was found in 5 of these cases. In general, mitotic figures were frequent. One case (21) showed monomorphous proliferation of medium- to large-sized lymphoid cells. This case was thus diagnosed as NHL of diffuse mixed cell type.

\section{Immunohistochemical study}

In the control cases, tumor cells in all 5 of the B-cell lymphomas showed positive reactivity for CD20. Small lymphocytes intermingling with large lymphoma cells were positive for T-cell markers including CD43, CD45RO, CD3 $\epsilon, \mathrm{CD} 4, \mathrm{CD} 5$ and CD8. These small lymphocytes also reacted with $\beta$ F1. The mantle zone lymphocytes in the preserved lymphoid follicles were positive for
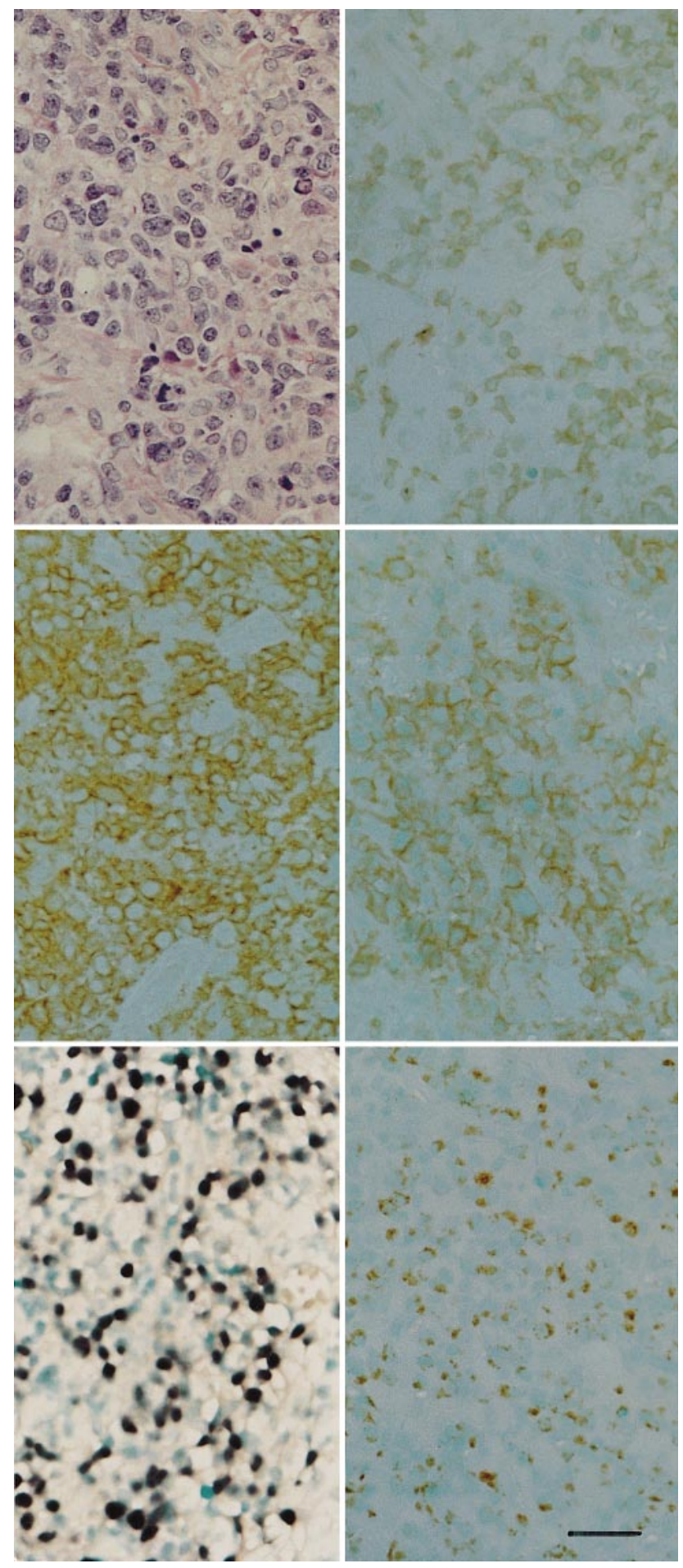

Figure 1 - Upper left: Diffuse proliferation of large cells with rich clear cytoplasm intermingling with small lymphocytes. H\&E. Proliferating cells were positive for CD3 $€$ (upper right), CD16 (middle left), CD56 (middle right) and TIA-1 (lower right). Lower left: In situ hybridization using EBER-1 probe showed positive signals in the nucleus of these cells. Scale bar: $30 \mu \mathrm{m}$.

CD5. All of 5 T-cell lymphoma cases expressed pan T-cell markers and 4 were positive for $\beta \mathrm{F} 1$ with $\mathrm{CD}^{+}, \mathrm{CD}^{-}$, and 1 case being $\mathrm{CD}^{-}, \mathrm{CD}^{+}$. Small lymphocytes intermingled with lymphoma cells were positive for NK cell markers including CD16, CD56 and CD57. 
As summarized in Table II, none of the 18 cases examined showed a B-cell immunophenotype or CD15 positivity. All of the PR cases were positive for CD16 and/or CD56, together with various T-cell markers including CD3 $\epsilon, \mathrm{CD} 4, \mathrm{CD} 5, \mathrm{CD} 43$ and CD45RO but negative for $\beta$ F1 (Fig. 1). Two cases (1 and 2) examined as frozen specimens were $\mathrm{CD} 2^{+}, \mathrm{CD} 56^{+}, \beta \mathrm{F} 1^{-}$, TCR $\delta$ $1^{-}$. Thus, all of the PR cases were tentatively considered to be NK cell or NK-like T-cell lymphoma. Twelve of these cases tested for TIA-1, known to react with cytotoxic granules of cytotoxic T cells or NK cells, showed positive granular staining in the cytoplasm. One case (21) that was diagnosed as diffuse mixed cell type was $\mathrm{CD}_{4}{ }^{+}, \mathrm{CD} 45 \mathrm{RO}^{+}, \mathrm{CD}^{-} 6^{-}$. This case was tentatively categorized as T-cell lymphoma.

\section{In situ hybridization for $E B V$}

Among the 16 cases examined, positive signals were detected in the nuclei of large atypical cells in $13(87 \%)$ of 15 PR cases but not in 1 case with ordinary NHL. Three $(23 \%)$ of these 13 PR cases with EBV genome were positive for LMP-1 expression in the cytoplasm.

\section{Southern blotting analysis for EBV genome clonality}

A monoclonal band was observed in 7 of 12 cases on Southern blotting analysis of Bam HI-digested DNA samples with an EBV-DNA probe corresponding to the sequence adjacent to TR (Fig. 2): 2 cases (4 and 21) with application of $10 \mu \mathrm{g}$ and 5 cases (1, $2,7,14$ and 20) with $20 \mu \mathrm{g}$ of genomic DNA from the lesions. The frequency of detection of the monoclonal band increased with application of larger amounts of DNA. Samples of $20 \mu \mathrm{g}$ of genomic DNA were not available for the remaining 5 cases, which were negative on analysis of $10 \mu \mathrm{g}$ of DNA. Therefore, clonality of EBV might have been detected in these 5 cases if larger amounts of DNA would have been available.

\section{DGGE method}

DGGE analysis did not show clonally rearranged bands in any of the present cases, including 7 with monoclonal proliferation of EBV-infected cells.

Based on the results of histological and immunohistochemical analyses, all of the 21 cases diagnosed as PR were judged to be NK cell lymphomas. Case 21 with diffuse mixed cell type of NHL showed the T-cell immunophenotype but germline configuration of the TCR $\gamma$ chain gene.

\section{DISCUSSION}

The patients discussed here presented with necrotic, granulomatous lesions in the upper respiratory tract, especially the nasal cavity. The predominance of male patients and rather young age at the onset of disease, together with polymorphous histological pattern of cellular proliferation, were identical with those in PR or NTL (Kassel et al., 1969; Tomita et al., 1995; Harabuchi et al., 1996). One case showed a rather monomorphous pattern of proliferation and was thus classified as NHL of diffuse mixed cell type. Such a monomorphous pattern of proliferation is occasional at the early stage and is relatively frequent at later stage of PR (Aozasa et al., 1995).

Immunohistochemical analysis was performed in 17 cases, 10 of which were found to be positive for CD43, CD45RO and CD8. Another 3 cases were $\mathrm{CD}^{+}$without positive immunoreactivity for CD43, CD45RO. These findings were roughly in agreement with those of previous immunohistochemical studies of cases with NTL (Ishii et al., 1982; Tomita et al., 1995; Harabuchi et al., 1996). Proliferating cells in 4 of 12 cases (33\%) were shown to be positive for CD5 using mAb 4C7. Previous studies usually with Leu 1 on frozen sections for detection of CD5 showed similarly positive rates, i.e., 20-43\% (van Gorp et al., 1994; Harabuchi et al., 1996). None of the present cases showed TCR $\beta$ ( $\beta$ F1) or $\delta$ chain (TCR $\delta$ 1) expression, which questions the T-cell nature of NTL.

CD2 is an antigenic phenotype of pan T cells and NK cells. Two cases (1 and 2) from which frozen sections were examined were $\mathrm{CD} 2^{+}$, which is consistent with previous reports on nasal lymphomas of NK and T-cell types (Petrella et al., 1996; Chiang et al., 1996; Jaffe et al., 1996). Cytoplasmic CD3 $\epsilon$ positivity is now regarded as a supporting finding for NK cell nature of the proliferating cells in NTL (Jaffe et al., 1996). In the current series, more than $60 \%$ of cases showed intracytoplasmic expression of CD3 $\epsilon$. Anti-CD56 antibody is known to recognize neuronal cell adhesion molecule (N-CAM) (Jaffe et al., 1996) and to show positive immunoreactivity with $\mathrm{NK}$ cell neoplasms ( $\mathrm{Ng}$ et al., 1987; Jaffe et al., 1996). More than $80 \%$ of the cases in the present series were positive for CD56, further supporting the NK cell

TABLE II - SUMMARY OF IMMUNOPHENOTYPE, EBV STUDY AND DGGE METHOD IN 21 PATIENTS WITH PR ${ }^{1}$

\begin{tabular}{|c|c|c|c|c|c|c|c|c|c|c|c|c|c|c|c|c|c|c|c|}
\hline \multirow{2}{*}{$\begin{array}{l}\text { Patient } \\
\text { number }\end{array}$} & \multicolumn{14}{|c|}{ Immunophenotype } & \multicolumn{3}{|c|}{ EBV } & \multirow{2}{*}{$\begin{array}{l}\mathrm{TCR} \gamma \text { gene } \\
\text { rearrangement }\end{array}$} & \multirow{2}{*}{ Histology } \\
\hline & CD20 & CD45RA & $\mathrm{CD} 43$ & CD45RO & $\mathrm{CD} 3 \epsilon$ & CD4 & CD5 & CD8 & CD15 & CD16 & CD56 & CD57 & TIA-1 & $\beta$ F1 & $\mathrm{CS} 1-4$ & PE2 & EBER & & \\
\hline 1 & - & nd & nd & nd & + & - & - & + & - & + & + & - & + & - & - & - & nd & G & PR \\
\hline 2 & - & - & + & + & + & - & - & - & - & - & + & - & + & - & - & - & nd & $\mathrm{G}$ & PR \\
\hline 3 & - & - & + & - & + & - & - & - & - & + & + & - & + & - & - & - & + & G & PR \\
\hline 4 & - & - & - & - & + & - & - & - & - & + & + & - & + & - & - & - & + & $\mathrm{G}$ & PR \\
\hline 5 & - & - & - & - & + & - & - & - & - & + & + & - & + & - & - & - & + & $\mathrm{G}$ & PR \\
\hline 6 & - & - & + & - & + & - & + & + & - & + & + & - & + & - & - & - & + & $\mathrm{G}$ & PR \\
\hline 7 & - & nd & + & + & + & nd & nd & nd & nd & nd & + & nd & nd & nd & + & nd & + & $\mathrm{G}$ & PR \\
\hline 8 & - & nd & + & - & + & nd & nd & nd & nd & nd & + & nd & nd & nd & - & nd & + & $\mathrm{G}$ & PR \\
\hline 9 & - & - & + & - & - & + & + & - & - & + & + & - & + & - & + & - & + & $\mathrm{G}$ & PR \\
\hline 10 & - & nd & + & + & - & nd & nd & nd & nd & nd & + & nd & nd & nd & + & nd & + & G & PR \\
\hline 11 & - & - & - & - & - & - & + & + & - & + & + & - & + & - & - & - & - & G & PR \\
\hline 12 & - & - & - & - & - & - & + & + & - & + & + & - & + & - & - & - & - & G & PR \\
\hline 13 & - & nd & + & + & nd & nd & nd & nd & nd & nd & + & nd & nd & nd & - & nd & + & $\mathrm{G}$ & PR \\
\hline 14 & - & nd & + & - & nd & nd & nd & nd & nd & nd & + & nd & nd & nd & - & nd & + & G & PR \\
\hline 15 & - & - & + & - & + & - & - & - & - & + & - & - & + & - & - & - & + & G & PR \\
\hline 16 & - & - & - & - & + & - & - & - & - & + & - & - & + & - & - & - & + & $\mathrm{G}$ & PR \\
\hline 17 & - & - & - & - & + & - & - & - & - & + & + & - & + & - & - & - & + & G & PR \\
\hline 18 & nd & nd & nd & nd & nd & nd & nd & nd & nd & nd & nd & nd & nd & nd & nd & nd & nd & G & PR \\
\hline 19 & nd & nd & nd & nd & nd & nd & nd & nd & nd & nd & nd & nd & nd & nd & nd & nd & nd & G & PR \\
\hline 20 & nd & nd & nd & nd & nd & nd & nd & nd & nd & nd & nd & nd & nd & nd & nd & nd & nd & $\mathrm{G}$ & PR \\
\hline 21 & - & nd & + & + & - & nd & nd & nd & nd & nd & - & nd & nd & nd & - & nd & - & $\mathrm{G}$ & Dmix \\
\hline
\end{tabular}

${ }^{1}$ Cases 1 and 2 from which frozen material was available were positive for CD2 and negative for TCR $\delta$ 1. G, germline; R, rearrangement; Dmix, diffuse mixed; nd, not done; EBER, EBV-encoded early RNA. 
(A)

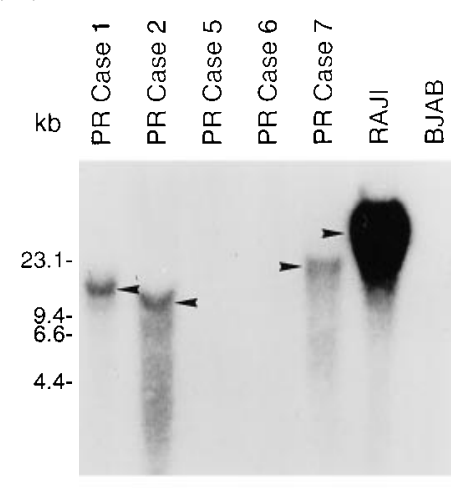

(B)

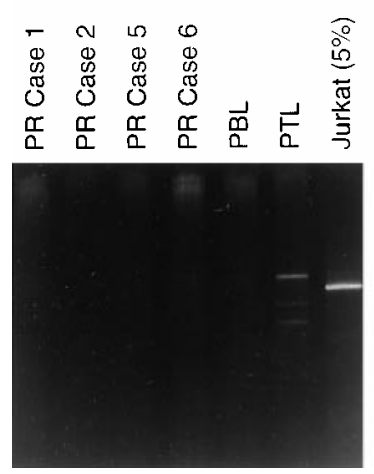

FIGURE 2 - (a) Southern blotting analysis for clonality of the EBV genome. Twenty micrograms of DNA was digested with Bam HI, electrophoresed in agarose gels, Southern blotted and hybridized with ${ }^{32}$ P-labeled EBV-DNA probe. DNA size markers are indicated on the left. Five-day exposure at $-80^{\circ} \mathrm{C}$. PR biopsy specimens and Raji cells contained a predominant TR of EBV (arrowheads). Raji, EBV-positive Burkitt's lymphoma cell line; BJAB, EBV-negative Burkitt's line. (b) DGGE patterns of PCR products amplified with $\mathrm{V}_{\gamma}$ primer and mixed $\mathrm{J}$ primers in a single reaction. Representative PR cases and peripheral blood leukocytes (PBL) from normal individual showed diffuse smears without predominant bands, representing polyclonal T-cell populations. Peripheral T-cell lymphoma (PTL) showed 3 discrete bands, representing a predominant clonal T-cell population. This pattern results from biallelic rearrangement with heteroduplex formation DNA from Jurkat cell line diluted to 5\% in DNA from PBL also showed 1 discrete band.

nature of the proliferating cells. However, it has become evident that CD56 does not have lineage or disease specificity for NK cells (Jaffe et al., 1996). CD57 is also a marker for NK cells, but none of our cases showed a positive immunoreactivity for this molecule, which is also in agreement with the results of previous studies on NTL (Ng et al., 1987) or nasal and nasal type T/NK cell lymphomas (Jaffe et al., 1996). CD16 is the Fc receptor through which NK cells mediate antibody-dependent cytotoxicity (Raulet et al., 1998). Previously, the Leu $11 \mathrm{~b} \mathrm{mAb}$ was used on frozen sections to detect CD16 and the results showed that about half of the NTL cases were CD16-positive (Ng et al., 1987; Harabuchi et al., 1996). In the present study, mAb $2 \mathrm{H} 7$, which can be used to stain routinely processed paraffin-embedded specimens, was used. Positive staining was observed in proliferating cells in 11 of 12 cases. $2 \mathrm{H} 7$ might be a sensitive marker for NK cell tumors. All of the present cases were positive for CD56 and/or CD16.

TIA is a $15 \mathrm{kDa}$ protein structurally related to the necrotic factor receptor family, which induces apoptotic cell death when introduced into permeabilized target cells (Kawakami et al., 1992). Antibodies to TIA-1 have been shown to be highly specific for the cytolytic granules of NK cells and cytotoxic T lymphocytes (CTLs) (Felgar et al., 1997). Thus, such antibodies could be useful in identification of specific subsets of lymphoid neoplasms derived from CTLs or NK cells. From the results of light and electron microscopic observations of leukemic cells in the peripheral blood of 1 case, a rare event in NTL, we showed that tumor cells had large granules in the cytoplasm, i.e., were large granular lymphocytes (LGL) (Aozasa et al., 1995). It is well known that NK cells and CTLs have the morphology of LGL (Timonen et al., 1981). Indeed, all of the current cases examined for TIA-1 showed positive immunoreactivity in the cytoplasm of tumor cells.

NTL is considered to be a lymphoid neoplasm. However, methods to confirm the clonality of proliferating cells in NTL have been quite limited. NTL has been reported to be one of the EBV-associated malignancies (Harabuchi et al., 1990; Tomita et al., 1995). The presence of clonal cellular proliferation of EBVinfected progenitor cells has been confirmed in NTL by examining the fused pattern of EBV terminal repeats (Raab-Traub et al., 1986). Indeed, in situ hybridization revealed positive signals for the EBV genome in all but 2 of the present cases. EBV genome clonality analysis confirmed the presence of monoclonal proliferation in 7 of these 12 cases. Clonal bands were initially found in 2 cases when analyzing $10 \mu \mathrm{g}$ of DNA, but they were also found in an additional 5 cases when $20 \mu \mathrm{g}$ of DNA was used. There seem to be problems in the sensitivity of the technique, and thus monoclonal bands might have been found in the remaining 5 cases if larger amounts of DNA had been available for examination. Only a small amount of DNA is usually available from nasal lesions accompanying necrotic changes.

Southern blotting analysis has been used for analysis of TCR gene rearrangement in NTL and has shown negative results in the vast majority of cases (Weiss et al., 1988; Emile et al., 1996; Jaffe et al., 1996). This procedure, however, has some disadvantages including limitation of sensitivity for clonal cell detection and misinterpretation of results due to artifacts such as non-specific degeneration of DNA prior to or during extraction from the tissues. Moreover, electrophoretic separation is based principally on the difference in length of DNA fragments digested with restriction enzymes, and thus the presence of monoclonal rearrangement could be confirmed only when mobility shifts were found relative to the germline configuration. If germline DNA and monoclonally rearranged DNA have the same size, the results would be interpreted as negative. The PCR-DGGE method does not suffer from these disadvantages of Southern blotting analysis and could be more sensitive and specific for detection of TCR $\gamma$ chain gene rearrangement (Bourgium et al., 1990). There have been few studies of TCR $\gamma$ chain gene rearrangement using PCR-DGGE in NTL cases: Petrella et al. (1996) reported that 4 cases with nasopharyngeal lymphomas showed the germline configuration. However, the presence of the monoclonal proliferation of the EBV genome-containing cells was not examined in these cases. As mentioned, samples from nasal lesions of NTL frequently contain necrotic tissues and small amounts or even no vivid tumor tissue. Therefore, confirmation of the presence of clonal cell proliferation in the lesional tissues from the nasal cavity is essential before application of the PCR-DGGE method. Clonally rearranged bands of the TCR $\gamma$ chain gene were not found in any of the present 21 cases with NTL including 7 cases with proven clonal proliferation of EBV genome-containing cells. These findings strongly suggest the absence of T-cell clones in NTL.

In conclusion, NTL cases were shown to be $\mathrm{CD}_{56}{ }^{+}$and/or $\mathrm{CD} 16^{+}, \mathrm{TIA}^{-} 1^{+}, \mathrm{CD} 2^{+}$and frequently $\mathrm{CD} 3 \epsilon^{+}$by immunohistochemistry. Tumor cells were frequently stained positively with mAbs for T lymphocytes but were negative for TCR $\beta$ and $\delta$ chain expression. Taken together with the absence of T-cell clones defined by sensitive genotyping, this strongly suggests that NTL is, in fact, a NK cell lymphoma. 


\section{REFERENCES}

Aozasa, K., Ohsawa, M., Tomita, Y., Tagawa, S. and Yamamura, T. Polymorphic reticulosis is a neoplasm of large granular lymphocytes with $\mathrm{CD}^{+}$phenotype. Cancer, 75, 894-901 (1995).

Bourgium, A., Tung, R., Gaulili, N. and Sklar, J., Rapid, nonradioactive detection of clonal T-cell receptor gene rearrangements in lymphoid neoplasms. Proc. nat. Acad. Sci. (Wash.), 87, 8536-8540 (1990).

Chiang, A.K.S., Srivastava, G., LaU, P.W.F. and Ho, F.C.S. Differences in T-cell-receptor gene rearrangement and transcription in nasal lymphomas of natural killer and T-cell types: implications on cellular origin. Hum. Pathol., 27, 701-707 (1996).

Emile, J.F., Boulland, M.L., Haioun, C., Kanavaros, P., Patrella, T., Delfau-Larue, M.H., Bensussan, A., FARCET, J.P. and Gaulard, P., CD5 ${ }^{-}$ $\mathrm{CD} 6^{+} \mathrm{T}$-cell receptor silent peripheral T-cell lymphomas are natural killer cell lymphomas. Blood, 87, 1466-1473 (1996).

Felgar, R.E., Macon, W.R., Kinney, M.C., Roberts, S., Pasha, T. and SALHANY, K.E., TIA-1 expression in lymphoid neoplasms. Identification of subsets with cytotoxic T lymphocyte or natural killer cell differentiation. Amer. J. Pathol., 150, 1893-1900 (1997).

Harabuchi, Y., Imai, S., Wakashima, J., Hirao, M., Kataura, A., Osato, T. and Kon, S., Nasal T cell lymphoma causally associated with EpsteinBarr virus. Clinicopathologic, phenotypic and genotypic studies. Cancer, 77, 2137-2149 (1996).

Harabuchi, Y., Yamanaka, N., Kataura, A., Imai, S., Kinoshita, T., Mizuno, F. and Osato, T., Epstein-Barr virus in nasal T-cell lymphoma in patients with lethal midline granuloma. Lancet, 335, 128-130 (1990).

Hodges, E., Edwards, S.E., Howell, W.M. and Smith, J.L., Polymerase chain reaction amplification analyses of clonality in T-cell malignancy including peripheral T-cell lymphoma. Leukemia, 8, 295-298 (1994).

Ishit, Y., Yamanaka, N., Ogawa, K., Yoshida, Y., Takami, T., MatsuUra, A., Isago, H., Kataura, A. and KiKUCHI, K., Nasal T-cell lymphoma as a type of so-called "lethal midline granuloma". Cancer, 50, 2336-2344 (1982).

JAFFE, E.S., Classification of natural killer (NK) cell and NK-like T-cell malignancies. Blood, 87, 1207-1210 (1996).

Jaffe, E.S., Chan, J.K.C., Su, I.-J., Frizzera, G., Mori, S., Feller, A.C. and Ho, F.C.S., Report of the workshop on nasal and related extranodal angiocentric T/natural killer cell lymphomas. Amer. J. surg., Pathol., 20, 103-111 (1996).

Kassel, S.H., Echevaria, R.A. and Guzzo, F.P., Midline malignant reticulosis (so-called "lethal midline granuloma"). Cancer, 23, 920-925 (1969).
Kawakami, A., Tian, Q., Duan, X., Streuli, M., Schlossman, S.F. and ANDERSON, P., Identification and functional characterization of a TIA-1 related nucleolysin. Proc. nat. Acad. Sci. (Wash.), 89, 8681-8685 (1992).

NG, C.S., Chan, J.K.C. and Lo, S.T.H., Expression of natural-killer-cell markers in non-Hodgkin's lymphomas. Hum. Pathol., 18, 1257-1262 (1987).

Petrella, T., Delfau-Larue, M.-H., Caillot, D., Morcillo, J.-L. Casasnovas, O., Portier, H., Gaulard, P., Farcet, J.-P. and Arnould, L Nasopharyngeal lymphomas: further evidence for a natural killer cell origin. Hum. Pathol., 27, 827-833 (1996).

RaAB-Traub, N. and FlynN, K., The structure of the termini of the Epstein-Barr virus as a marker of clonal cellular proliferation. Cell, 47, 883-889 (1986).

Raulet, D.H., Correa, I., Corral, L., Dorfman, J. and Wu, M.F., Inhibitory effects of class I molecules on murine NK cells: speculations on function, specificity and self-tolerance. Semin. Immunol., 7, 103-107 (1998).

Theodorou, I, Bigorgne, C., Delfau, M-H., Lathet, C., Cochet, G., Vidaud, M., RAPHAEl, M., GaUlard, P. and FARCET, J.-P., VJ rearrangements of the TCR $\gamma$ locus in peripheral T-cell lymphomas: analysis by polymerase chain reaction and denaturing gradient gel electrophoresis. $J$ Pathol., 178, 303-310 (1996).

Timonen, T., Ortaldo, J.R. and Heberman, R.B., Characteristics of human large granular lymphocytes and relationship to natural killer and $\mathrm{K}$ cells. $J$. exp. Med., 153, 569-582 (1981).

Tomita, Y., Ohsawa, M., Mishiro, Y., Kubo, T., Maeshiro, N., KoJya, S., NodA, Y. and AoZASA, K., The presence and subtype of Epstein-Barr virus in B- and T-cell lymphomas of sino-nasal region from the Osaka and Okinawa districts of Japan. Lab. Invest., 73, 190-196 (1995).

van Gorp, J., Liu, W.-P., Jacobse, K., Yong-Huei, L., Feng-Yuan, L., De WEGER, R.A. and LI, G., Epstein-Barr virus in nasal T-cell lymphomas (polymorphic reticulosis/midline malignant reticulosis) in Western China. J. Pathol., 173, 81-87 (1994).

Weiss, L.M., Chen, Y.Y., LiU, X.F. and ShiBAta, D., Epstein-Barr virus and Hodgkin's disease: a correlative in situ hybrization and polymerase-chainreaction study. Amer. J. Pathol., 139, 1259-1265 (1991).

Weiss, L.M., Picker, L.J., Grogan, T.M., Warnke, R. and Sklar, J., Absence of clonal beta and gamma T-cell receptor gene rearrangements in subset of peripheral T-cell lymphomas. Amer. J. Pathol., 130, 436-442 (1988). 